\title{
Inheritance of Three Major Genes Involved in the Synthesis of Aliphatic Glucosinolates in Brassica oleracea
}

\author{
G. Li, A. Riaz, S. Goyal, ${ }^{1}$ S. Abel, and C.F. Quiros ${ }^{2}$ \\ Department of Vegetable Crops, University of California, Davis CA 95616
}

\begin{abstract}
AdDITIONAL INDEX WORDs. glucoraphanin, isothiocyanates, nutraceuticals, sinigrin, anticarcinogens
Aвstract. Inheritance of three major genes involved in synthesis of aliphatic glucosinolates (GSL) was followed in segregating populations of Brassica oleracea $\mathrm{L}$. generated from three crosses: broccoli $\mathrm{x}$ cauliflower, collard $\mathrm{x}$ broccoli, and collard $x$ cauliflower. Two of these genes, GSL-PRO and GSL-ELONG, regulate sidechain length. The action of the former results in three-carbon GSL, whereas action of the latter produces four-carbon GSL. We determined that these two genes act and segregate independently from each other in $\mathrm{B}$. oleracea. The double recessive genotype produces only trace amounts of aliphatic GSL. The third gene, GSL-ALK controls sidechain desaturation and, as it has been observed in Arabidopsis thaliana (L.) Heynh., we found that this gene cosegregates with a fourth gene, GSL-OH, that is responsible for sidechain hydroxylation. Elucidation of the inheritance of major genes controlling biosynthesis of GSL will allow for manipulation of these genes and facilitate development of lines with specific GSL profiles. This capability will be important for improvement of Brassica breeding lines with high content of desirable GSL, like glucoraphanin, a demonstrated precursor of anticarcinogenic compounds. Additionally, this work is the first step towards cloning the major genes of the aliphatic GSL pathway, and to use these clones in transformation strategies for further crop enhancement.
\end{abstract}

A number of studies suggest that consumption of vegetables, in particularcrops such as broccoli [Brassica oleracea(Italica Group)] and other crucifers, reduces the incidence of cancer in humans and other mammals (Block et al., 1992; Fahey and Talalay 1995, Prochaska et al., 1992). This seems to be due to the presence of inducers of phase II enzymes, that detoxify carcinogens and mutagens in various mammalian organs (Prestera et al., 1996; Prochaska et al., 1992; Talalay et al., 1995). In broccoli, the isothiocyanate sulfuraphane, derived from the GSL glucoraphanin by the action of the enzyme myrosinase, was identified as a potent inducer of these enzymes, conferring protection against mammary tumor growth in rats after treatment with dimethyl benzanthracene, a carcinogenic agent (Zhang et al., 1992, 1994). Glucoraphanin is one of the major GSL present in some crops of B. oleracea such as broccoli (Farnham et al., 2000), cauliflower [B.oleracea (Botrytis Group)], cabbage [B. oleracea (Capitata Group)] and brussels sprouts $[B$. oleracea (Gemmifera Group)] (Rosa et al., 1997). Although certain GSL derivatives have a protective effect against cancer (Rosa et al., 1997), there are some that may have detrimental effects such those derived from alkenyl GSL in rapeseed seed meal (Brassica napus L.). These act as antinutrients affecting not only animal growth and development, but also lowering food intake. Additionally, modified isothiocyanates from the aliphatic GSL progoitrin may have goitrogenic effects in animals (Rosa et al., 1997). Therefore, a common breeding objective for Brassica L. crops grown for oilseed or forage is to lower the amount of these antinutritional GSL (Bell, 1993).

GSL are a diverse class of thioglucosides that are synthesized by many species of the order Capparales, including Brassica and Arabidopsis Heynh. The GSL molecule consists of two parts; a common glycone moiety and a variable aglycone side chain (Fenwick et al., 1983; Rosa et al. 1997). The aglycone part may contain

Received for publication 4 Oct. 2000. Accepted for publication 12 Mar. 2001. We are indebted to D. Nevins and K. Bradford for reading the manuscript and to V. D'Antonio, D. Grubb, and H. Gross for technical assistance. This work was supported in part by U.S. Dept. Agr. Fund for Rural America grant to S. Abel and C.F. Quiros. The cost of publishing this paper was defrayed in part by the payment of page charges. Under postal regulations, this paper therefore must be hereby marked advertisement solely to indicate this fact.

${ }^{1}$ Department of Agronomy and Range Sciences.

${ }^{2}$ Corresponding author; e mail: cfquiros@ucdavis.edu. aliphatic, indolyl, or aromatic side chains and is derived from a corresponding $\alpha$-amino acid. The general GSL biosynthetic pathway proposed by Underhill (1980), Larsen (1981) and (Haughn et al., 1991) considers that aliphatic GSL are derived from methionine. Genetic studies in Arabidopsis thaliana (Mithen et al., 1995; Mithen and Campos 1996) and Brassica sp. (Magrath et al. 1993; 1994) support the biochemical pathway proposed for biosynthesis of aliphatic GSL. The synthesis of these compounds is determined by a simple genetic system containing two distinct sets of genes, one determining sidechain elongation and the second one chemical modification of the sidechains. Aliphatic GSL profiles vary considerably in A. thaliana ecotypes and Brassica sp. These GSL are synthesized in the following sequence: methylsulfinylalkyl, alkenyl and hydroxy types, which can be divided into three-carbon (3C), four-carbon (4C), and five-carbon (5C) groups based on their sidechain length.

In A. thaliana, several genes involved in the GSL pathway have been identified by genetic analysis, including GSL-ELONG, GSL$A L K, G S L-O H P$, and GSL-OH (Campos de Quiros et al., 2000; Magrath et al., 1994; Mithen et al., 1995; Mithen and Campos 1996). The GSL-ELONG locus regulates sidechain length, whereas GSL$A L K$ controls sidechain desaturation. GSL-OHP and GSL-OH are responsible for sidechain hydroxylation (Magrath et al., 1993; 1994). In B. oleracea, presence of homologs to GSL-PRO, GSL$O X I D, G S L-E L O N G, G S L-A L K$ and GSL-OH loci (Giamoustaris and Mithen,1996; Mithen et al., 1995) has been inferred from inspection of GSL profiles. In rapeseed, (Magrath et al., 1993; Parkin et al., 1994) a similar set of genes has also been proposed. Therefore, the genetic evidence suggests that biosynthesis of GSL is highly conserved in Brassica and Arabidopsis. However, many steps in sidechain elongation, glycone formation, and aglycone modification remain to be characterized biochemically and genetically.

According to the present model, the 3C, 4C, and 5C GSL are closely related biosynthetically because all of them originate from the same precursor, methionine (Fig. 1). In this model, it is expected that the presence of the dominant allele for the GSL-ELONG gene will result in 4C GSL, whereas presence of the dominant allele for $G S L-P R O$ will result in 3C GSL. Although it is clear that plants carrying both dominant alleles will produce both $3 \mathrm{C}$ and $4 \mathrm{C}$ GSL, 
Table 1. Composition of the GSL phenotypes reported in this paper for major three loci involved in the biosynthesis of aliphatic GSL.

\begin{tabular}{ll}
\hline \hline Phenotype & GSL composition \\
\hline $\mathrm{PRO}^{+} / \mathrm{ELONG}^{+} / \mathrm{ALK}^{+}$ & Glucoiberin, progoitrin, ${ }^{\mathrm{z}}$ glucoraphanin, sinigrin, gluconapin \\
$\mathrm{PRO}^{-} / \mathrm{ELONG}^{+} / \mathrm{ALK}^{+}$ & Glucoraphanin and progoitrin \\
$\mathrm{PRO}^{\mathrm{z}} / \mathrm{ELONG}^{+} / \mathrm{ALK}^{-}$ & Glucoiberin, glucoraphanin \\
$\mathrm{PRO}^{+} / \mathrm{ELONG}^{-} / \mathrm{ALK}^{+}$ & Sinigrin, glucoiberin \\
$\mathrm{PRO}^{-} / \mathrm{ELONG}^{+} / \mathrm{ALK}^{-}$ & Glucoraphanin \\
$\mathrm{PRO}^{+} / \mathrm{ELONG}^{-} / \mathrm{ALK}^{-}$ & Glucoiberin \\
$\mathrm{PRO}^{-} / \mathrm{ELONG}^{-} / \mathrm{ALK}^{-}$ & Trace amounts of GSL
\end{tabular}

${ }^{\mathrm{z}}$ Results from the action of a fourth locus, GSL-OH, where allele GSL-OH hydeoxylates gluconapin into progoitrin (Fig. 1).

it is not clear what the phenotype of the plant is when both alleles are recessive. Another question is whether it is possible to manipulate independently the $3 \mathrm{C}$ and $4 \mathrm{C}$ GSL determining genes. In this paper, we address these questions by following segregation of the major GSL chain elongation and modification genes. These results lay the foundation for isolation of important genes involved in the GSL pathway, which will ultimately make it possible to genetically engineer Brassica crops with optimal contents of specific GSL.

\section{Materials and Methods}

Plant material. The following $B$. oleracea populations were used for the inheritance studies: 1) 52 recombinant inbred (RI, $\mathrm{F}_{5}$ ) and $88 \mathrm{~F}_{2}$ plants of collard $\mathrm{x}$ broccoli. 2) $89 \mathrm{RI}\left(\mathrm{F}_{6}\right)$ lines of collard $X$ cauliflower, and 3) $195 \mathrm{~F}_{2}$ plants of a doubled haploid (DH) cauliflower $x$ DH broccoli cross.

GSL ANALYSIS. Analysis of GSL was performed with the protocol based on Kraling et al. (1990), which was modified for leaf extraction (instead of seeds). For this purpose $\approx 2 \mathrm{~g}$ of fresh leaves collected from 6 -week-old seedlings were ground in liquid nitrogen. The tissue was extracted twice with $70 \%$ methanol at $80^{\circ} \mathrm{C}$ for $10 \mathrm{~min}$. After applying the supernatant to a DEAE-Sephadex A-25 column (Sigma, St. Louis, Mo.), the GSL were converted into desulfo-GSL with sulfatase $\left(0.5 \%\right.$ enzyme in water for $12 \mathrm{~h}$ at $24^{\circ} \mathrm{C}$, Sigma HI type). The desulfo-GSL were then eluted by adding $1.5 \mathrm{~mL}$ distilled water. The resulting mixture was separated by highperformance liquid chromatography (HPLC) (model SCL-10AVP; Shimadzu, Columbia, Md.) fitted with an ultraviolet detector set at $230 \mathrm{~nm}$ and a Lichrosorb $100 \mathrm{RP}-18$ column (Alltech Assoc. Inc., Deerfield, Ill.) using a linear solvent gradient from $1 \%$ to $19 \%$ acetonitrile in water over $20 \mathrm{~min}$. The flow rate was $1.5 \mathrm{~mL} \cdot \mathrm{min}^{-1}$ at $32^{\circ} \mathrm{C}$. The HPLC chromatogram was compared to the desulfo-GSL profile of 'Linetta' rapeseed, a cultivar used widely as a standard for GSL identification to compare the peaks with the corresponding GSL. The presence of desulfosinigrin and desulfoglucoraphanin peaks was confirmed by using pure authentic sinigrin (Sigma) as an internal standard. Qualitative assessment of GSL was done visually by the presence or absence of the specific peaks. On the basis of this assessment, we assigned the phenotypes of each plant in the segregating populations as described in Table 1. GSL content was quantified with glucotropaeolin (E.M. Science, Gibbstown, N.J.) as an internal standard.

\section{Results and Discussion}

BrocCOLI X CAULIFlower POPUlation. This population was useful to follow segregation of two genes involved in the GSL pathway, GSL-PRO determining synthesis of $3 \mathrm{C}$ aliphatic GSL and GSL-ELONG determining synthesis of 4C GSL (Fig. 1). The parental cauliflower $\mathrm{DH}$ line for this cross contained only the $3 \mathrm{C}$ side chain GSL, sinigrin, and glucoiberin (Fig. 2A). Therefore, the phenotype of this line is GSL-PRO ${ }^{+} / \mathrm{GSL}_{-E L O N G} / \mathrm{GSL}_{-} \mathrm{ALK}^{+}$. The expression level of $G S L-A L K$ seems to be very low in this parent, because sinigrin content was lower than glucoiberin content. The DH broccoli parent contained only glucoraphanin (Fig. 2B), so its phenotype was GSL-PRO-/GSL-ELONG ${ }^{+} / \mathrm{GSL}^{-} \mathrm{ALK}^{-}$. The GSL profile of the resulting $\mathrm{F}_{1}$ plants contained four major aliphatic GSL, namely glucoiberin, progoitrin, glucoraphanin, and sinigrin (Fig. 2C). As expected from the genetic constitution of the parental lines, the $\mathrm{F}_{1}$ was heterozygous at the GSL-PRO, GSL-ELONG, and GSL$A L K$ loci. The presence of progoitrin also indicated activity of $G S L$ $O H$, which regulates sidechain hydroxylation. $G S L-O H$ hydroxylates $4 \mathrm{C}$ but not $3 \mathrm{C}$ sidechains, and it requires a functional $G S L-A L K$ allele to perform the modification reaction. Therefore, it is difficult to know in this population which parental line had a functional allele for the GSL-OH locus, because there were no $4 \mathrm{C}$ side chain GSL in the cauliflower parent, and GSL-ALK was nonfunctional in the broccoli parent. In any case, the low level of both progoitrin and

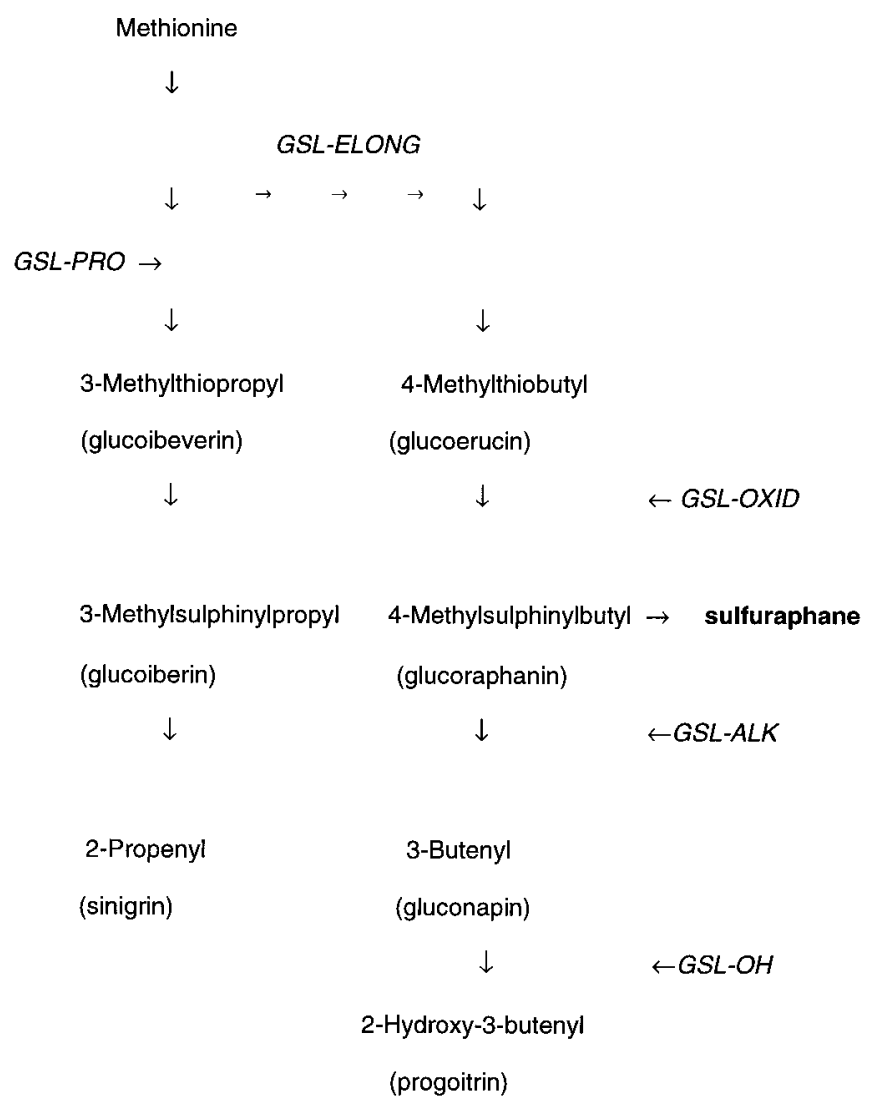

Fig. 1. Model for aliphatic GSL biosynthesis in B. oleracea, including the inferred major genes controlling this process (adapted from Mithen et al., 1995, 1996). 
sinigrin in the $\mathrm{F}_{1}$ progeny, which was $<10 \%$ of all the aliphatic GSL, indicates the expression level of $G S L-A L K$ and $G S L-O H$ was very

A

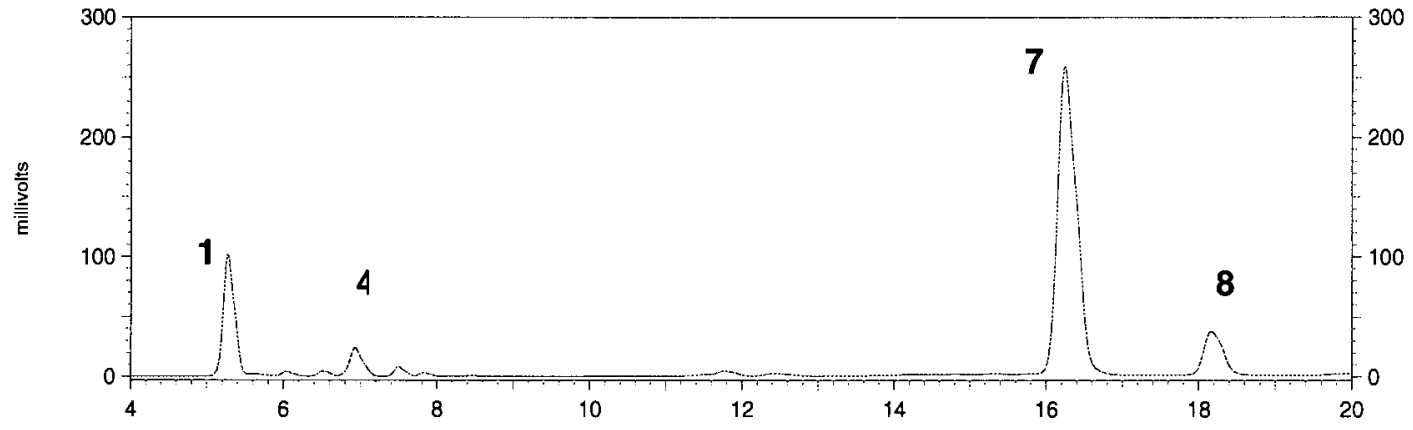

B
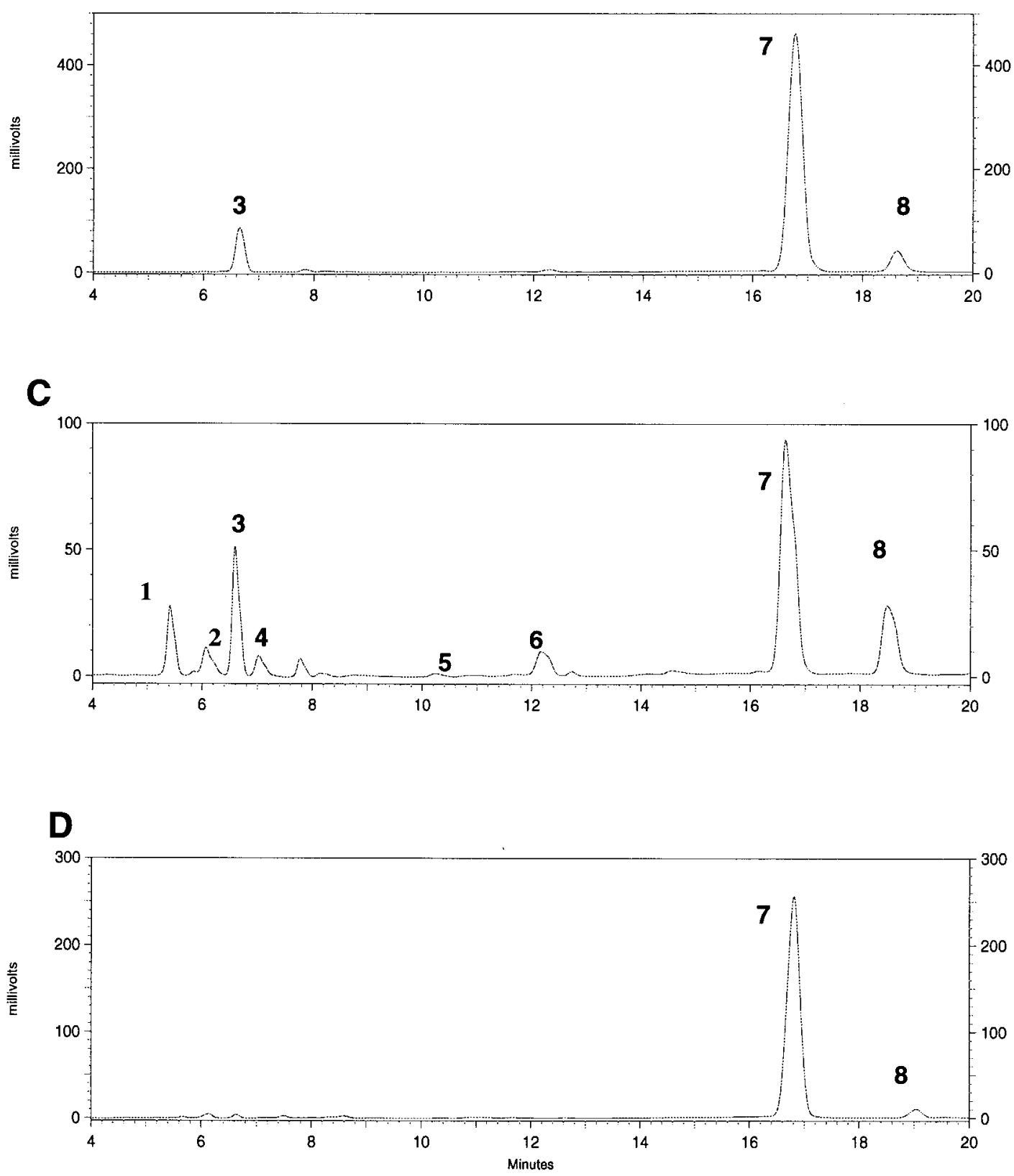

low. For this reason, the inheritance of these two genes was not followed in this $\mathrm{F}_{2}$ population because their low expression makes it difficult to accurately classify the phenotype of the plants based on their GSL profiles. The $\mathrm{F}_{2}$ plants segregated as expected for independent assortment for the $G S L-P R O$ and $G S L$ ELONG genes (9:3:3:1 ratio, $\chi^{2}=0.44, P=0.93,3 \mathrm{df}$ ) (Table 2). The phenotypes of these four segregating groups are GSL-PRO+/GSL-

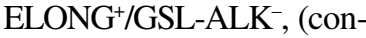
taining glucoiberin and glucoraphanin); GSL$\mathrm{PRO}^{+} / \mathrm{GSL}_{-} \mathrm{ELONG}^{-} / \mathrm{GSL}-$ $\mathrm{ALK}^{-}$(containing glucoiberin, but no glucoraphanin), GSL-PRO/GSL-ELONG ${ }^{+} / \mathrm{GSL}_{-}$ $\mathrm{ALK}^{-}$(containing glucoraphanin, but no glucoiberin), and GSL-PRO ${ }^{-}$ GSL-ELONG-/GSL-ALK(plants containing either traces, $(<1 \%$ of total GSL) or nondetectable amounts of aliphatic GSL (Fig. 2D).

Two aspects of our results have important implications for crop improvement. First, the plants without detectable aliphatic GSL confirm that the $3 \mathrm{C}$ and $4 \mathrm{C}$ GSL are independently regulated by the $G S L-P R O$ and GSL-ELONG genes. Therefore it is possible to manipulate $3 \mathrm{C}$ and $4 \mathrm{C} \mathrm{GSL}$ content independently, making it possible to channel the

Fig. 2. GSL profiles for parental lines and derived progeny from the cross of doubled haploid lines of broccoli with cauliflower. (A) Cauliflower parent of phenotype GSL-PRO $/$ GSL-ELONG-/GSL$\mathrm{ALK}^{+}$, (B) broccoli parent of phenotype GSL-PRO-/GSL$\mathrm{ELONG}^{+} / \mathrm{GSL}^{-\mathrm{ALK}^{-}}$, (C) $\mathrm{F}_{1}$ hybrid of phenotype GSL-PRO ${ }^{+}$ GSL-ELONG ${ }^{+} / \mathrm{GSL}^{-\mathrm{ALK}^{+} \text {, and }}$ (D) recombinant double recessive individual of phenotype GSLPRO-/GSL-ELONG-/GSL-ALKPeak identities: 1 = glucoiberin, 2 $=$ progoitrin, $3=$ glucoraphanin, 4 = sinigrin, $5=$ gluconapin, $6=4$ hydroxyglucobrassicin, $7=$ glucobrassicin, $8=4$ methoxyglucobrassicin $(6,7$ and 8 are indolyl GSL). 
Table 2. Segregation ratios (expected values in parenthesis) for four progenies segregating for three major aliphatic GSL genes.

\begin{tabular}{|c|c|c|c|c|}
\hline \multirow[b]{2}{*}{$\begin{array}{l}\text { Phenotype } \\
\text { for GSL }\end{array}$} & \multicolumn{4}{|c|}{ Population $^{2}$} \\
\hline & $\begin{array}{l}\mathrm{c} \times \mathrm{b}(\mathrm{RI}) \\
(1: 1: 1: 1)^{\mathrm{y}}\end{array}$ & $\begin{array}{l}\mathrm{c} \times \mathrm{b}\left(\mathrm{F}_{2}\right) \\
(9: 3: 3: 1)^{\mathrm{y}}\end{array}$ & $\begin{array}{c}\text { c x cw }(\mathrm{RI}) \\
(1: 1)^{\mathrm{y}}\end{array}$ & $\begin{array}{c}\mathrm{b} \times \mathrm{cw}\left(\mathrm{F}_{2}\right) \\
(9: 3: 3: 1)^{\mathrm{y}}\end{array}$ \\
\hline$\overline{\mathrm{PRO}^{-} / \mathrm{ELONG}^{+} / \mathrm{ALK}^{-}}$ & $14(13)$ & $5(5.5)$ & & $37(36.6)$ \\
\hline $\mathrm{PRO}^{-} / \mathrm{ELONG}^{+} / \mathrm{ALK}^{+}$ & $8(13)$ & $18(16.5)$ & & \\
\hline $\mathrm{PRO}^{+} / \mathrm{ELONG}^{+} / \mathrm{ALK}^{-}$ & $13(13)$ & $17(16.5)$ & $36(44.5)$ & $112(109.7)$ \\
\hline $\mathrm{PRO}^{+} / \mathrm{ELONG}^{+} / \mathrm{ALK}^{+}$ & $17(13)$ & $48(49.5)$ & $53(44.5)$ & \\
\hline $\mathrm{PRO}^{-} / \mathrm{ELONG}^{-} / \mathrm{ALK}^{-}$ & & & & $9(12.2)$ \\
\hline $\mathrm{PRO}^{+} / \mathrm{ELONG}^{-} / \mathrm{ALK}^{-}$ & & & & $37(36.6)$ \\
\hline$\chi^{2}$ values & 1.76 & 0.14 & 1.62 & 0.44 \\
\hline
\end{tabular}

${ }_{\mathrm{z}} \mathrm{c}=$ collard, $\mathrm{b}=$ broccoli, $\mathrm{cw}=$ cauliflower, $\mathrm{RI}=$ recombinant inbreds.

yexpected ratios.

GSL pathway toward the synthesis of glucoraphanin by increasing expression level of GSL-ELONG and reducing expression of GSL$P R O$. This may lead to development of $B$. oleracea crops with high content of the putative anticarcinogen, sulfuraphane. Secondly, the
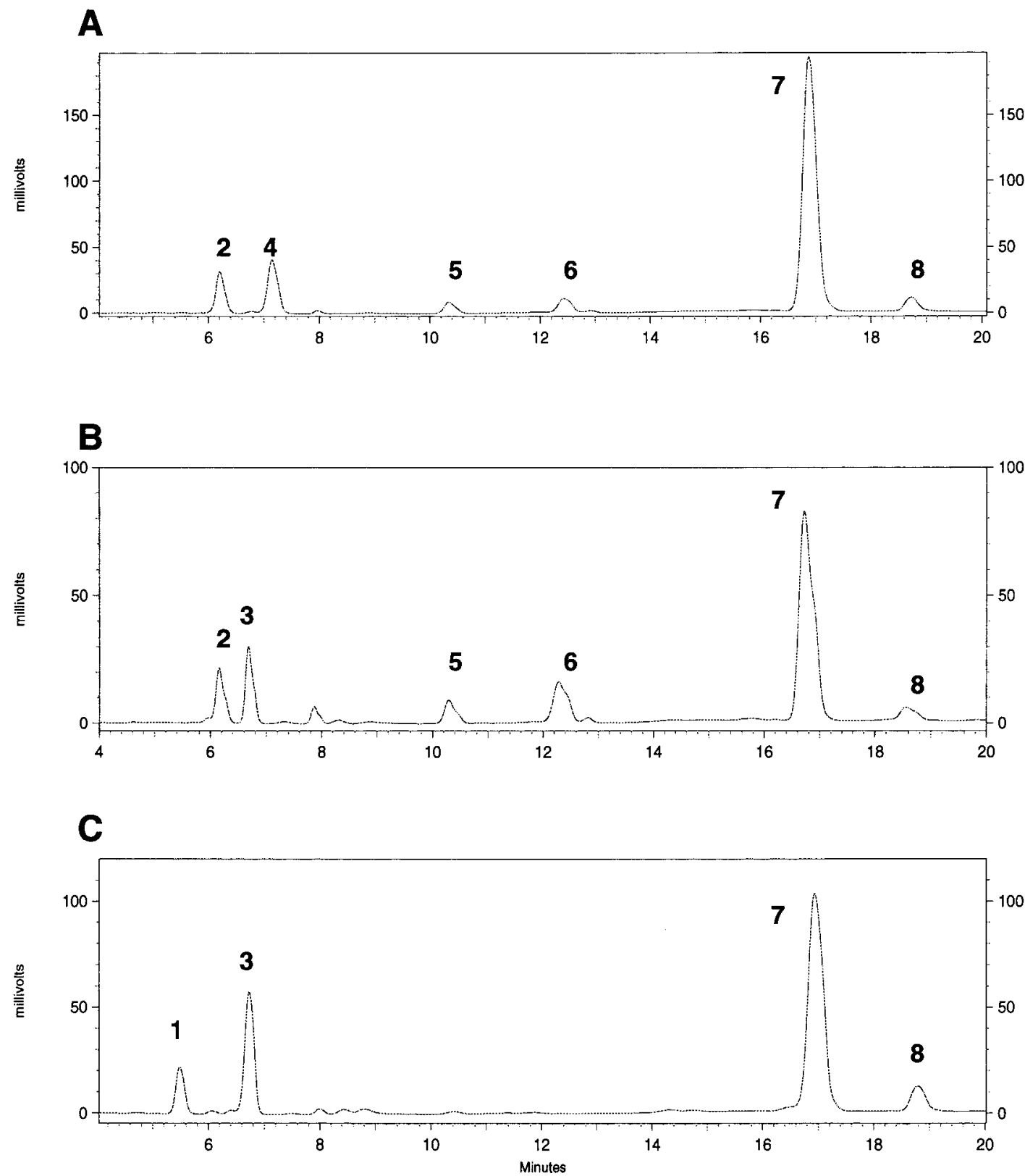

double recessive genotype may be valuable in rapeseed breeding to further reduce GSL content to improve the quality of seed meal used as livestock feed.

Collard X BRocColi populations. These populations allowed us to follow segregation of two genes in the aliphatic GSL pathway, GSL-PRO and $G S L-A L K$ (Fig. 1). The GSL profile of the collard parent indicated that over $90 \%$ of its aliphatic GSL were represented by sinigrin and progoitrin $(42 \%$ and $55 \%$, respectively). Thus, its phenotype is GSL-PRO ${ }^{+} /$ GS L-ELON G ${ }^{+} / \mathrm{GSL}$ $\mathrm{ALK}^{+} / \mathrm{GSL}^{-} \mathrm{OH}^{+}$. The $G S L$ $A L K$ and $G S L-O H$ genes are expressed at high levels because glucoiberin and glucoraphanin were nearly absent and completely converted into sinigrin and progoitrin, respectively (Fig. 3A).However, the independent phenotypes for $G S L-A L K$ and $G S L-O H$ could not be resolved in this population because they clearly cosegregated. This situation has been also observed in $A$. thaliana (Mithen et al., 1995). Therefore, GSL-ALK and $G S L-O H$ loci either cor-

Fig. 3. GSL profiles of the collard parent used to generate collard $\mathrm{x}$ broccoli segregating progenies and of two $\mathrm{F}_{2}$ individuals. (A) Collard parental line of phenotype GSL$\mathrm{PRO}^{+} / \mathrm{GSL}_{-} \mathrm{ELONG}^{+} / \mathrm{GSL}$ $\mathrm{ALK}^{+} / \mathrm{GSL}^{-} \mathrm{OH}^{+},(\mathbf{B})$ recombinant individual of phenotype GSL-

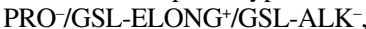
and $(\mathbf{C})$ recombinant individual of phenotype GSL-PRO ${ }^{+} / \mathrm{GSL}$ ELONG $^{+} /$GSL-ALK-. For peak identities, see caption of Fig. 2. 
respond to a single gene encoding a bifunctional enzyme catalyzing desaturation and hydroxylation, or they represent two tightly linked loci.

The broccoli parent had a similar profile as that of the DH broccoli line used in the previous cross. The phenotype of this line

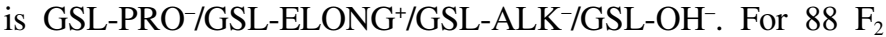
plants of this progeny, four phenotypic groups were observed segregating in the expected 9:3:3:1 ratio for two independent genes, $G S L-P R O$ and $G S-A L K\left(\chi^{2}=0.14, P=0.99,3 \mathrm{df}\right)$ (Table 2). One phenotypic group, GSL-PRO-/GSL-ELONG ${ }^{+} / \mathrm{GSL}^{-} \mathrm{ALK}^{-}$had the same GSL profile as the broccoli parent, which contained only glucoraphanin. Another phenotypic group, GSL-PRO-/GSL$\mathrm{ELONG}^{+} / \mathrm{GSL}_{-} \mathrm{ALK}^{+}$, contained progoitrin and glucoraphanin(Fig. 3B) and a third group, GSL-PRO ${ }^{+} / \mathrm{GSL}_{-E L O N G} / \mathrm{GSL}_{-} \mathrm{ALK}^{-}$, contained glucoiberin and glucoraphanin (Fig. 3C). These represent the expected recombinant phenotypes. The fourth and largest group had the same phenotype as the collard parent, GSL-PRO ${ }^{+}$GSL$\mathrm{ELONG}^{+} / \mathrm{GSL}_{-} \mathrm{ALK}^{+}$, containing all four major aliphatic GSL. Fifty-three RI lines of the population from the same cross, collard $\mathrm{X}$ broccoli, could also be classified into the same four groups as observed for the $\mathrm{F}_{2}$ plants segregating in the expected $1: 1: 1: 1$ ratio $\left(\chi^{2}=1.76, P=0.62,3 \mathrm{df}\right)$ (Table 2$)$.

Collard X CaUliflower POPUlation. Only the segregation of $G S L-A L K$ and GSL-OH was followed in this population. The cauliflower parent of this cross contained only glucoiberin and glucoraphanin, therefore, its phenotype was GSL-PRO ${ }^{+} / \mathrm{GSL}-$ $\mathrm{ELONG}^{+} / \mathrm{GSL}-\mathrm{ALK}^{-} / \mathrm{GSL}-\mathrm{OH}^{-}$. The alleles for $G S L-A L K$ and $G S L-O H$ were recessive in this parent because no desaturation and hydroxylation products were detected. As indicated in the previous cross, the phenotype of the collard parent was GSL-PRO ${ }^{+} / \mathrm{GSL}-$ $\mathrm{ELONG}^{+} / \mathrm{GSL}_{-} \mathrm{ALK}^{+} / \mathrm{GSL}_{-} \mathrm{OH}^{+}$. Again $\mathrm{GSL}-\mathrm{ALK}$ and $\mathrm{GSL}-\mathrm{OH}$ cosegregated in this cross. If recombination between these two genes had occurred, one would expect to find plants containing gluconapin instead of progoitrin. None of the segregating plants from either the collard $\mathrm{x}$ broccoli or the collard $\mathrm{x}$ cauliflower populations had this GSL profile. Only two GSL profiles were detected in the RI segregating lines. One had the same phenotype as the cauliflower parent, GSL-PRO ${ }^{+} / \mathrm{GSL}-\mathrm{ELONG}^{+} / \mathrm{GSL}-\mathrm{ALK}^{-}$, containing glucoiberin and glucoraphanin, and the other had the same phenotype as the collard parent, GSL-PRO ${ }^{+} / \mathrm{GSL}_{-} \mathrm{ELONG}^{+}$/

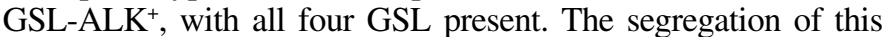
population fits the expected $1: 1$ ratio $\left(\chi^{2}=1.62, P=0.21\right.$, $1 \mathrm{df}$ ) (Table 2) for a single segregating gene.

\section{Conclusion}

The populations generated in the present study will be essential to clone the major genes involved in the synthesis of aliphatic GSL in $B$. olerace $a$ crops using the respective $A$. thaliana homologs. For example, one of the genes (GSL-ELONG) has been cloned from $A$. thaliana (Campos de Quiros, et al., 2000). Based on this sequence, we have identified several clones from a $B$. oleracea bacterial artificial chromosome library containing the homologous gene. This library was developed from the DH broccoli parent used to generate the first cross described in this paper (Li et al., 2000). A marker obtained from one of these clones cosegregates with $4 \mathrm{C}$ GSL. We are now in the process of sequencing the $B$. olerace $\mathrm{GSL}$ ELONG homolog. Additionally, using these populations, we found several molecular markers closely linked to GSL-ALK and GSL$P R O$ genes. Our future plans are to do complementary transformation to confirm cloning of the major GSL genes in Brassica.

\section{Literature Cited}

Bell.J.M. 1993. Factors affecting the nutritional value of canola meal: A review. Can. J. Animal. Sci. 73:679-697.

Block, G., B. Patterson, and A. Subar. 1992. Fruit, vegetables, and cancer prevention: A review of epidemiological evidence. Nutr. Cancer 18:1-29.

CamposdeQuiros,H.,R.Magrath,D.McCallum,J.Kroymann,D.Scnabelrauch, T.Mitchell-Olds, andR.Mithen.2000. $\alpha$-Ketoacidelongationandglucosinolate L biosynthesis in Arabidopsis thaliana. Theor. Appl. Genet. 101:429-437.

Fahey,J.W.andP.Talalay. 1995. The roleof crucifers incancerchemoprotection p. 87-93. In: D.L. Gustine and H.E. Flores (eds.). Phytochemicals and health. Amer. Soc. of Plant Physiologists. Rockville, Md.

Farnham, M.W., K. K.Stephenson and J. W. Fahey. 2000. Capacity of broccoli to induce a mammalian chemoprotective enzyme varies among inbred lines. J. Amer. Soc. Hort. Sci. 125:482-488.

Fenwick, G.R., R.K. Haeney, and W.J. Mullin. 1983. Glucosinolates and their breakdown products in food and food plants. Crit. Rev. Food Sci. Nutr. 18:123-301.

Giamoustaris, A. and R.F. Mithen. 1996. The effect of modifying glucosinolate content of leaves of oilseedrape (Brassicanapus ssp.oleifera) on itsinteraction with specialist and generalist pests. Ann. Appl. Biol. 126:347-363.

Haughn, G.W., L. Davin, M. Giblin, and E.W. Underhill. 1991. Biochemical genetics of plant secondary metabolites in Arabidopsis thaliana: The glucosinolates. Plant Physiol. 97:217-226.

Kraling, K., G. Robbelen, W. Thies, M. Herrmann, and R. Ahmadi. 1990. Variation of seed glucosinolates in lines of Brassica napus. Plant Breeding 105:33-39.

Larsen, P.O. 1981. Glucosinolates.p. 501-525.In:E. Conn(ed.). The biochemistry of plants vol.7. Academic Press, New York.

Li, G., R. Ahmad, and C.FQuiros. 2000. Identifying genes controlling synthesis of aliphatic glucosinolates in B. oleracea for map-based cloning. Brassica 2000, 3rd Intl. Soc. Hort. Sci. Intl. Symp. on brassicas, HRI, Wellesbourne United Kindom. p. 62.

Magrath, R., F. Bano, M. Morgner, I. Parkin, A. Sharpe, C. Lister, C. Dean, J. Turner, D. Lydiate, and R. Mithen. 1994. Genetics of aliphatic glucosinolates. I. Side chain elongation in Brassica napus and Arabidopsis thaliana. Heredity 72:290-299.

Magrath, R., C. Herron, A. Giamoustaris, and R. Mithen.1993. The inheritance of aliphatic glucosinolates in Brassica napus. Plant Breeding 111:55-72.

Mithen, R. and H. Campos. 1996. Genetic variation of aliphatic glucosinolates in Arabidopsis thaliana and prospects for map based gene cloning. Entomol. Expt. Appl. 80:202-205.

Mithen, R., J. Clarke, C. Lister, and C. Dean.1995. Genetics of aliphatic glucosinolates. III. Side chain structure of aliphatic GSL in Arabidopsis thaliana. Heredity 74:210-215.

Parkin, I., R. Magrath, D. Keith, A. Sharpe, R. Mithen, and D. Lydiate. 1994. Genetics of aliphatic GSL. II. Hydroxylation of alkenyl glucosinolates in Brassica napus. Heredity 72:594-598.

Prestera,T.,J.W.Fahey,W.D.Holtzclaw,C.Abeygunawardana,J.L. Kachinski, and P. Talalay. 1996. Comprehensive chromatographic and spectroscopic methods for the separation and identification of intact glucosinolates. Anal. Biochem. 239:168-179.

Prochaska, H.J., A.B. Santamaria, and P. Talalay. 1992. Rapid detection of inducers of enzymes that protect against carcinogens. Proc. Natl. Acad. Sci. (USA) 89:2394-2398.

Rosa,E.A., R. K.Hearney, G.R.Fenwick, andC.A.Portas. 1997. Glucosinolates in crop plants. Hort. Rev. 19:99-215.

Talalay, P., J.W. Fahey, W.D. Holtzclaw, T. Prestera, and Y. Zhang. 1995. Chemoprotection against cancer by phase 2 enzyme induction. Toxicol. Lett. 82/83:173-179.

Underhill, E.W. 1980. Glucosinolate. Encyclopedia of plant physiology (new series). vol. 8. Springer Verlag, Berlin.

Zhang, Y., T.W. Kensler, C.G. Cho, G.H. Posner, and P. Talalay. 1994. Anticarcinogenic activities of sulforaphane and structurally related synthetic norbornyl isothiocyanates. Proc. Natl. Acad. Sci. USA 91:3147-3150.

Zhang, Y.,P.Talalay, C.G.Cho, andG.H.Posner. 1992. Amajorinducer of anticarcinogenic protective enzymes from broccoli: Isolation and elucidation of structure. Proc. Natl. Acad. Sci. USA 89:2399-2403. 